\title{
CYBERBULLYING AMONG SCHOOL CHILDREN ${ }^{3}$
}

\begin{abstract}
Modern information technologies are widely used in everyday communication among children and adults alike. In addition to the benefits that the use of modern media provides, one faces the possibilities of their abuse for the purpose of hurting others. Among students one encounters cyberbullying as a form of an inadequate use of modern media. Since the aforementioned phenomenon is of recent date and the manners of its manifestation become increasingly complex with the development of modern media one needs to understand more clearly the specificity and the manner of expressing this form of bullying. This paper aims to specify the meaning of the term cyberbullying, its manifestation forms, participants' roles in cyberbullying, as well as the consequences of such behaviour in order to understand this phenomenon more clearly for the purpose of educating the school staff to be able to suppress it.
\end{abstract}

Key words: cyberbullying, forms of cyberbullying, traditional bullying, bullies, victims, bystanders.

\section{Introduction}

The Internet, mobile phones and other modern tools have irreversibly changed the manner in which people communicate nowadays. Modern information technologies have become fully integrated into our everyday lives, and they have especially been embraced by children and the young. Nevertheless, in addition to numerous benefits which the advancement and availability of modern technology bring to everyday life, there are also possibilities of their abuse for the purpose of hurting others.

One of the manners of using modern media for negative purposes is cyberbullying which is present to a certain extent among students in primary and secondary schools. The aforementioned phenomenon is of recent date and the manners of its manifestation become increasingly complex with the development of modern media. Consequently, one needs to understand more clearly its specificities in order to secure a suitable reaction to its manifestations.

\footnotetext{
${ }^{1}$ Received February 2020 / Accepted April 2020

${ }^{2}$ E-mail: marija.markovic@filfak.ni.ac.rs

${ }^{3}$ The paper is a part of the project "Enhancing professional competencies of prospective pedagogues within the framework of undergraduate academic studies of pedagogy" (360/1-16-5-01), which is carried out at the University of Nis - Faculty of Philosophy. This study was financially supported by the Ministry of Education, Science and Technological Development of the Republic of Serbia.
} 


\section{Definition of the term cyberbullying}

Cyberbullying is defined as a phenomenon "when someone repeatedly makes fun of another person online or repeatedly picks on another person through email or text message or when someone posts something online about another person that they don't like" (Hinduja \& Patchin, 2009, according to O'Moore, 2012: 209; Hinduja \& Patchin, 2010c, according to Donegan, 2012: 35), i.e. as a "wilful and repeated harm inflicted through the use of computers, cell phones, and other electronic devices" (Hinduja \& Patchin, 2009, Patchin \& Hinduja, 2006, according to Hinduja \& Patchin, 2010: 208). This form of inadequate behavior is also defined as intentional aggression expressed by using electronic devices (Dooley, Pyzalski \& Cross, 2009, according to Morrow \& Downey, 2013: 536).

Similarly to traditional bullying, cyberbullying is wilful (intentional), repeated (it represents a pattern of one's behaviour), it causes negative consequences for the victim (of which the victim is fully aware), the bully is more powerful (in physical, social or psychological respect) than the victim, but cyberbullying also implies the application of various technical tools intended for communication in the digital space (which makes it different from traditional bullying) (Bilić, 2014; Hinduja \& Patchin, 2010; Ryan \& Curwen, 2013). It can build on traditional bullying, which provides the bully with the opportunity to constantly bully the victim by means of technology (Griezel, Finger, Bodkin Andrews, Craven \& Seeshing Yeung, 2012; O’Moore, 2012).

Cyberbullying involves sending and posting hurtful or cruel text and/or images by means of the Internet or other devices used for digital communication, such as mobile phones, computers, tablets, etc. Messages or photos can appear on personal web pages or they can be sent by email or shared on social networks by means of chat rooms, Messenger, Internet forums, mobile phones, etc (Bilić, 2014; Ercegovac Reić, 2016; Feinberg \& Robey, 2009; Griezel et al., 2012; Hase, Goldberg, Smith, Stuck \& Campain, 2015; Hinduja \& Patchin, 2010; Jose, Kljakovic, Scheib \& Notte, 2011; Ryan \& Curwen, 2013; Twemlow \& Sacco, 2008). Similarly to traditional bullying, cyberbullying can also include disregard, disrespect, teasing or some other form of aggressive behavior towards the victim, as well as spreading rumours about someone, stalking or posing physical threats by using various means of digital communication (Hinduja \& Patchin, 2010). It can be enforced by individuals or groups (Bilić, 2014; Smith, Mahdavi, Carvalho, Fisher, Russell \& Tippett, 2008, according to Erentaité, Bergman \& Žukauskiené, 2012: 181; Hinduja \& Patchin 2009, Smith 2012, according to DePaolis \& Williford, 2015: 378).

Cyberbullying most frequently occurs when children are at home, but it can also occur when they are at school (Feinberg \& Robey, 2009). A major feature of cyberbullying is the fact that a child can be exposed to such abusive behaviour of others for 24 hours every day. Hence, cyberbullying can run continuously, and not merely in a child's direct contact with peers (Donegan, 2012; Feinberg \& Robey, 2009; Machackova \& Pfetsch, 2016).

Another important property of this form of bullying is the anonymity of the perpetrator who can easily hide his/her identity and thus anonymously engage in 
aggressive behavior against others (Bilić, 2014; Ercegovac Reić, 2016; Ryan \& Curwen, 2013). It is believed that anonymity significantly encourages further engagement in cyberbullying (Bilić, 2014; Donegan, 2012). It is precisely anonymity that is considered to be the most significant factor which provides bullies with the sense of false courage, invincibility and unlimited power to behave in an unacceptable manner. It appears that anonymity decreases self-awareness and self-control and facilitates this sort of aggressive behavior. On the other hand, it is believed that the computer monitor is an obstacle which disables a bully to see a victim's reaction and thus contributes to the increased cruelty and decreased responsibility in a bully. Due to anonymity the bully more easily attacks the victim, whereby the victim is not capable of physical retaliation. The distancing effect which technology has on the youth nowadays frequently allows them to say or do more ruthless things in comparison to what is typical for face-toface bullying. Since cyberbullying can be enforced at any time of the day and from different locations, whereby the victim is constantly available, it is believed that this contributes to the sense of power in the perpetrator. For the same reasons victims have an intense feeling of insecurity because they cannot protect themselves, there is no safe haven where they could seek protection, harmful content is visible to a large number of peers and they can witness them at any time of the day. As a result victims can have a strong feeling that bullying is ubiquitous and that they are in a helpless and hopeless situation. Furthermore, victims often have no knowledge of who the bully is, while harmful content is difficult to remove.

The cyberbully can be known to the victim, but this does not have to be the case. As we have previously stated, cyberbullies can quite often remain anonymous, which makes it difficult, even impossible to ascertain their identity. They can secretly cooperate with their friends who are inclined towards bullying behaviour, which makes it even more difficult to establish the perpetrator. Though there is no clear evidence that the young people who engage in traditional bullying also resort to cyberbullying, it does seem possible that victims of physical bullying can engage in cyberbullying as a form of retaliation against their tormentors (Feinberg \& Robey, 2009).

It is believed that cyberbullying represents a form which, due to everyday use of modern communication technologies, has evolved past the traditional bullying (Barlett \& Coyne, 2014; Donegan, 2012). Nevertheless, there are authors who believe that cyberbullying is a special form of bullying which has its own specific properties in comparison to traditional bullying (Barlett \& Coyne, 2014; Bilić, 2014; Olweus, 2012). While traditional bullying and cyberbullying are similar with respect to their form and techniques, these forms of aggressive behavior do differ.

In the research conducted by Jose et al. (2011) the authors studied the stability and interplay between the traditional (face-to-face) bullying, traditional victimization, cyberbullying and victimization in adolescents over time. The sample consisted of around 1700 adolescents aged 11 to 16 years. The results showed that all four dynamics were moderately stable over time. It has been revealed that the following variables become increased and predictable over time: traditional bullying and traditional victimization; traditional bullying and cyberbullying; traditional bullying 
and cyber victimization. The results show the connection between the bullying behaviour and victimization by means of traditional bullying and cyberbullying, but their interpersonal dynamics are not identical. It has been established that traditional victimization is more stable than cyber victimization. The authors have established a weak two-way connection between the traditional bullying and traditional victimization, while such relationship has not been established between cyberbullying and cyber victimization. Nevertheless, it has been established that cyberbullying can be a predictor of cyber victimization. Students prone to cyberbullying run the risk of being cyber-victimized later, while it is highly unlikely for the victims of cyberbullying to become cyberbullies. It has been established that there is a positive two-way relationship between the traditional bullying and cyberbullying over time, which indicates that students who resorted to traditional bullying can over time become inclined towards cyberbullying, and vice versa. Such positive two-way relationship has been established between traditional bullying and cyber victimization which indicates that one type of victimization can lead to another.

A relationship between traditional bullying and cyberbullying is indicated by the results of various related research studies. For instance, the research which comprised 660 students from the $3^{\text {rd }}$ to $5^{\text {th }}$ grade of various USA primary schools showed that $17,7 \%$ respondents had been victims of cyberbullying (first and foremost during online gaming). The results also show that children who were victims of cyberbullying had also been both victims of traditional bullying and bullies, as well as that they had significantly more positive attitudes towards cyberbullying and negative attitudes towards defending oneself and others from cyberbullying. It is possible that children who had been victims of different forms of bullying could seek indirect manners of revenge, which makes it more probable that they would resort to cyberbullying and relational forms of aggression (DePaolis \& Williford, 2015).

In a similar research conducted in Lithuania on a sample of 1667 secondary school students (58\% of girls), aged from 15 to 19 years it was studied whether victimization at school could eventually grow into cyber victimization. The authors considered three forms of traditional bullying (verbal, physical and relational) and cyber victimization by means of mobile phones and computers (e-messages, text messages via phone, chats, applications and chat rooms, etc.). Likewise, the results show that $35 \%$ victims of traditional victimization were also bullied in cyberspace. Specifically, adolescents who had gone through mostly verbal and relational bullying at school were in bigger danger of victimization in cyberspace a year later, while this was not recorded in relation to traditional forms of bullying (Erentaité, Bergman \& Žukauskiené, 2012).

There are some other interesting data indicating that a large majority of students who were victims of cyberbullying were also victimized through traditional bullying. Both forms of victimization were independently connected with negative outcomes. However, when the authors investigated into traditional bullying it was established that cyberbullying did not remain a predictor of negative outcomes regarding mental health. On the contrary, when cyberbullying was scrutinised, traditional bullying 
remained a significant predictor of negative outcomes to mental health. These results show that though traditional bullying and cyberbullying can be directed towards the same victims, traditional bullying is more strongly connected with negative psychological outcomes to the victims. When traditional bullying was controlled, cyberbullying was more strongly connected with psychological consequences in boys than in girls (Hase et al., 2015).

Research results indicate that traditional bullying and cyberbullying are connected with some other variables which can be significant when planning suitable intervention. For instance, the research which aimed at establishing whether there was a connection between social and psychological factors and traditional bullying and cyberbullying provided data collected on a sample of 1344 children aged 10 years. Correlating variables were bullying/victimization, depression, anxiety, coping strategies, self-respect and psychopathology. Parents provided demographic data, information regarding general health of children and presence of the ADHD syndrome. The authors studied the connection between the given variables and traditional bullying and cyberbullying of children at the age of 12 . It has been established that male sex and depression are connected with both types of bullying and victimization. Living with a single parent was related to the act of traditional bullying, while more conspicuous ADHD syndrome was related to victimization. Poor academic achievement and lower self-esteem were connected with bullying and victimization through cyberbullying, and anxiety symptoms with being engaged in cyberbullying. It was established that previous bullying behaviour was connected with victimization through cyberbullying, but not with other outcomes. Higher levels of anxiety were connected with the eventual engagement in cyberbullying. It indicates that cyberbullying has different predictors in comparison to traditional bullying, which should be taken into consideration when planning intervention measures (Yang, Stewart, Kim, Kim, Shin, Dewey, Maskey \& Yoon, 2013).

Likewise, it has been established that regarding morality the perpetrators of traditional bullying and cyberbullying have similar characteristics which relate to certain moral aspects such as: the lack of a sense of guilt, disobedience, malice, unreliability. Gender was not observed as a significant variable in that respect (Menesini, Nocentini \& Camodeca, 2013).

As a result of different manners of defining the term cyberbullying, the established frequency rates of cyberbullying and victimization vary from one study to another. Percentages also vary depending on the population which is scrutinised (i.e. gender, age), forms of cyberbullying which are the subject of measurement, the manner of measurement used to assess occurrences of cyberbullying (von Marées \& Petermann 2012, according to DePaolis \& Williford, 2015: 378). The literature on cyberbullying is inconsistent regarding the gender and age differences among those who are perpetrators and victims of cyberbullying (Barlett \& Coyne, 2014; Griezel, et al., 2012; Opsenica Kostić, Panić \& Cakić, 2015). Accordingly, it is very difficult to provide a definitive response regarding the frequency of cyberbullying among the young (von Marées \& Petermann 2012, according to DePaolis \& Williford, 2015: 378). 
Nevertheless, it appears that with age (in relation to primary school where research studies show that cyberbullying is less present in comparison to other forms of bullying) the possibility of cyberbullying increases, since the research conducted on samples of secondary school students and older adolescents show a larger frequency of cyberbullying, first and foremost through the Internet (Ercegovac Reić, 2016).

A research conducted in Ireland on a sample of 3004 students - 1009 girls $(33,6 \%)$ and 1995 boys $(66,4 \%)$ aged 12 to 16 years it has been established that traditional bullying is more frequent than cyberbullying; that cyberbullying is more frequently encountered among girls than among boys; that the category of perpetrators includes those students who simultaneously resort to both traditional bullying and cyberbullying; that one out of 20 students stated that he/she was simultaneously a victim and a cyberbully (more frequent in girls than in boys) which indicates that cyberbullying is a two-way phenomenon (like traditional bullying). It has been observed that, when trying to overcome the problem of cyberbullying, girls are more prone to seek social support of their families and friends, which is not the case with boys. Likewise, girls react assertively to cyberbullying (they insist upon the perpetrator to stop), unlike boys who are prone to physical bullying as a reaction to cyberbullying (O’Moore, 2012).

Cyberbullying, like traditional bullying, leaves significant negative consequences on victims (Hinduja \& Patchin, 2010; Morrow \& Downey, 2013; O'Moore, 2012). It is even considered that cyberbullying leaves more devastating negative consequences than traditional bullying (Hinduja \& Patchin, 2010; O’Moore, 2012). Negative consequences of cyberbullying can be even more devastating than the consequences of traditional bullying for the following reasons: 1) the possibility of incessant reception and access to electronic messages (unlike verbal statements), because those are kept on electronic devices, sites, etc; 2) the easiness and freedom with which one sends hurtful, demeaning and threatening notes to other people; 3) difficulties in discovering inappropriate behaviour, identifying the perpetrator, proving or confirming the misdeed and sentencing the perpetrator; 4) the fact that victimization goes beyond one's school, playground, bus stop and neighbourhood due to the ever present computers, mobile phones and other devices and networked lives that adolescents lead; 5) increasing number of potential victims and bullies as a result of accepting new communication technologies, devices and mediums for mutual interaction (Hinduja \& Patchin, 2010: 208-209).

\section{Types of cyberbullying}

With respect to types of cyberbullying, it is possible to distinguish between direct (open threats and harassment) and indirect cyberbullying (posting falsehoods on web pages, etc.) (Bilić, 2014; Griezel et al., 2012), while, according to the manner of presenting the hurtful content, one can distinguish between visual and text cyberbullying (Griezel et al., 2012), whereby quite frequently various forms of cyberbullying are mutually combined and repeated (Bilić, 2014). 
Bilić (2014) distinguishes between the following forms of cyberbullying:

1) harassment and intimidation - implies sending offensive messages by means of modern communication tools. Those can occur in the following forms: flaming which, when repeated, can turn into online harassment while intensive online harassment which implies numerous actions such as intimidation and threats (with physical bullying) and which can result in a long-term sense of fear, is called cyber stalking.

2) posting falsehood - implies sending and posting gossips or rumours which can harm one's reputation and it is usually referred to as cyber denigration. Misinformation deals with spreading false information through email or web pages, such as posting edited photos. Outing involves revealing secrets, sharing sensitive, unpleasant private information and photos which have most frequently been obtained in a previous close relationship with the person in question.

3) specific forms of cyberbullying - such as online exclusion, which implies intentional exclusion from online groups or deleting one from a list of friends; impersonation, password theft or identity theft, sending materials to bring the victim into dangerous situations or to harm her/his reputation; happy slapping whereby several students most frequently physically attack the victim while one of them makes a video clip (by mobile phone or camera) and then sends the material to others or publishes everything online (there is most frequently more than one instance of such bullying in real and virtual world); sexting, which is described as sending, receiving and forwarding nude and partially nude photos, videos and sexually explicit text messages by using different devices, whereby those whose videos and photos are thus distributed can end up being publicly disgraced, mocked as well as blackmailed; fraping (a blended word combining Facebook and raping), which implies violent intrusion of a "friend" into someone's profile in order to send unpleasant messages to others on behalf of the profile owners (Carrick-Davies, 2012, according to Bilić, 2014: 76). Other researchers identified additional forms of bullying such as griefing - harassing others in gaming communities and trolling - incessant posting of snide comments on the Internet (Slonje, Smith \& Frisén, 2013, according to DePaolis \& Williford, 2015: 379).

It is necessary, of course, to indicate that the aforementioned categorisation is not exhaustive and that one is expected to encounter new forms of cyberbullying with the further advent of technology and of the manners in which young people use modern information technologies for mutual communication (Bilić, 2014; DePaolis \& Williford, 2015).

\section{Participant roles in cyberbullying}

As is the case with traditional bullying, within the scope of cyberbullying one can make a distinction between students who are bullies, bullies/victims and victims (Feinberg \& Robey, 2009; Opsenica Kostić, Panić \& Cakić, 2015). 
Within the category of a bully it is possible to distinguish between the following subtypes: vengeful angel - who does not perceive oneself as a bully but more as a careful person, because he/she often tries to protect friends who are victims of traditional bullying or cyberbullying; power-hungry cyberbullies - who wish to exercise their authority and control over others through fear, while they themselves are quite often victims of bullying. Some tend to call it the revenge of nerds cyberbullying because those bullies are frequently physically more weak and marked by their peers as unpopular, or they are skilled at using technology; mean girls cyberbullying often takes place in a group, whereby the bullies are often bored and they seek fun; inadvertent cyberbullies who do not have intention of imposing harm but act without thinking about the consequences of their actions (Feinberg \& Robey, 2009).

Young people who are at risk of becoming victims of cyberbullying are characterised by the following: vulnerable, immature or socially naïve adolescents who possibly lack sufficient knowledge and skills to efficiently make decisions; young teenagers who have overprotective or naïve parents, but who probably have healthy peer relationships and a good value system; the young who have momentary problems in their relationship with parents and/or peers and are currently emotionally disturbed; the young who face major current challenges related to personal mental health and disruptions in their relationship with parents, school and/or peers (Feinberg \& Robey, 2009).

As is the case with traditional bullying (Salmivalli, 1999, 2001, 2010; Salmivalli, Huttunen \& Lagerspetz, 1997; Salmivalli \& Isaacs, 2005; Sallmivalli, Kaukiainen, Kaistaniemi \& Lagerspetz, 1999; Salmivalli, Kaukiainen \& Voeten, 2005; Salmivalli, Voeten \& Poskiparta, 2011), cyberbullying also includes a special category of students signified as observers (Opsenica Kostić, Panić \& Cakić, 2015). The research which our authors Opsenica Kostić, Panić and Cakić (2015) conducted on a sample of 285 students from Sremska Mitrovica (141 young men, 144 young ladies) aged 15 to 19 years, showed that around $40 \%$ of respondents do not participate in any form of cyberbullying, $14,7 \%$ of respondents bear witness to bullying while around $45 \%$ of respondents can be perceived as participants in cyberbullying either in the role of bullies $(6 \%)$ or victims (13\%) and bullies/victims (26\%). Likewise, it has been noted that participants' roles in cyberbullying are mutually interconnected, whereby one person can have more than one role. It has been established that the bully/victim group has high scores on a scale for witness roles as well, which implies that those adolescents are both actively and passively involved in cyberbullying.

A research in Germany studied into observers' reactions to situations of traditional bullying and cyberbullying. Two possible reactions of observers were considered: providing help for the victims and encouraging bullies. The sample included 321 students (aged 12 to 18 years; $M=14.99 ; 44 \%$ of girls). It has been established that young people react in a similar fashion to both traditional bullying and cyberbullying. Those young people who reacted to traditional bullying by offering support to the victims reacted in the same way to cyberbullying, while those who were inclined to encourage the bullies in cases of traditional bullying exhibited 
similar behaviour in the case of cyberbullying as well. Nevertheless, one should bear in mind that one does not deal here with a linear relationship. Though in some cases observers reacted by offering support to the victim of traditional/cyberbullying, it is possible that in some other situations they might have reacted differently. The authors also studied into the connection between observers' reactions and normative belief regarding verbal and cyber aggression, as well as into the levels of affective and cognitive empathy. Both types of normative beliefs (approving such behaviour) were positive predictors of the encouragement of the bully, while normative belief regarding verbal aggression also predicted support for the victims of cyberbullying. Both kinds of empathy predicted support in the event of traditional bullying, while only affective empathy predicted support in case of cyberbullying. Authors have not established the connection between affective or cognitive empathy and bully encouragement. Moreover, observers' tendencies to react by offering support to the victim or by encouraging the bully were rather consistent in both traditional bullying and cyberbullying, but there was no connection between offering support to victims and encouraging bullies (Machackova \& Pfetsch, 2016).

\section{Consequences of cyberbullying}

Negative consequences of cyberbullying can occur in emotional, social and academic domain of an individual's functioning (Ryan \& Curwen, 2013). Emotional consequences relate to strong negative emotions (shame, fear, frustrations, hopelessness, loneliness, sadness, helplessness, anxiety, and depression), low selfesteem, bad perception of oneself, etc. Social consequences can be reflected in being excluded by peers and avoiding others, etc, though it has been observed that research results fail to be unambiguous. Academic consequences relate to cutting school, imposing educational measures at school, absenteeism, underachievement at school, etc. However, it is not quite clear whether social and academic problems occur as a result of cyberbullying or as their precursor.

Emotional reactions in cyberbullying victims move from anxiety (more present in girls than in boys) to anger (more present in boys than in girls) and fear (O'Moore, 2012). In other research studies it has been established that cyberbullying causes stronger negative emotional reactions (frustration, anger, sadness) in girls more than in boys (Bannink, Broeren, von de Looij Jansen, de Waart \& Raat, 2014; Hinduja \& Patchin, 2009c, according to Donegan, 2012: 36).

Furthermore, it has been established that certain protective factors can mitigate the negative effects of cyberbullying. Aside from a strong connection between cyber victimization and lower self-esteem, it has been established, for instance, that cyber victimization and communication between a mother and an adolescent are significant predictors of the adolescent's level of self-esteem. Furthermore, communication between parents and adolescents appeared to be a significant connection moderator between cyber victimization and self-esteem, so much so that victimized adolescents 
who have better communication with their parents also have higher self-esteem in comparison to those who have poor communication with their parents (Özdemir, 2014).

It has been established that children who were included in cyberbullying whether as bullies or victims contemplate suicide more often and there is a greater probability that they might commit suicide in comparison to those who have not been included in this form of bullying, whereby victims more often contemplate suicide in comparison to bullies (Hinduja \& Patchin, 2010). One should emphasise that cyberbullying most frequently does not constitute the only cause of depression and suicidal thoughts, but it certainly can increase the instability, sense of worthlessness and hopelessness, especially if it occurs frequently and if traumas are extremely malicious, which strongly influences adolescents who are an especially sensitive and vulnerable group due to their developmental characteristics (Bilić, 2014).

\section{Conclusion}

The problems of cyberbullying and that of traditional bullying represent the prioritized institutional as well as a wider social problem the solution of which requires a dedicated and systematic approach, bearing in mind long-term negative consequences for every participant. In order for the school to react properly to the phenomenon of cyberbullying it is necessary to develop suitable teaching competences in the given field. Thus, it is necessary to continually work on the development of teaching competences in the given field, but also on developing competences of the entire school staff. One should also improve general conditions and secure the necessary means, as well as improve the co-operation at an institutional level, etc.

Likewise, the phenomenon of cyberbullying should not be observed as a problem which can exclusively be solved at school and by means of school. More significant positive effects regarding the decrease in cyberbullying one can expect only if one considers and aims at removing wider social factors which can decrease the effects of previously applied preventive measures and activities at the school level and contribute to their further solidification and frequency. Furthermore, due to a large number of variables which can contribute to the frequency of cyberbullying, it is necessary to conduct further research with the aim of establishing the components of efficient prevention programmes, while simultaneously intensify the co-operation between the researchers and practitioners in the given field.

\section{References}

Bannink, R., Broeren, S., van de Looij - Jansen, M. P., de Waart, G. F., Raat, H. (2014). "Cyber and Traditional Bullying Victimization as a Risk Factor for Mental Health Problems and Suicidal Ideation in Adolescents”. Plos One, 9(4), pp. 1-7. 
Barlett, C., Coyne, M. S. (2014). "A Meta-Analysis of Sex Differences in Cyber-Bullying Behavior: The Moderating Role of Age". Aggressive Behavior, 40, pp. 474-488.

Bilić, V. (2014). Correlates and outcomes of cyberbullying and cybervictimization. Ed. M. Orel. The new vision of future technologies. (pp. 71-84). Ljubljana: Eduvision.

DePaolis, K., Williford, A. (2015). “The Nature and Prevalence of Cyber Victimization Among Elementary School Children". Child and Youth Care Forum, 44, pp. 377-393.

Donegan, R. (2012). "Bullying and cyberbullying: History, statistics, law prevention and analysis". The Elon Journal of Undergraduate Research in Communications, 3(1), pp. 33-42.

Ercegovac Reić, I. (2016). “Doživljeno vršnjačko nasilje: relacije s dobi, spolom, razrednim ozračjem i školskim uspjehom" [Bullying experience: relations with age, gender, school environment, and academic achievements]. Školski vjesnik: časopis za pedagogijsku teoriju i praksu, 65(2), pp. 251-271.

Erentaité, R., Bergman, L. R., Žukauskiené, R. (2012). “Cross-contextual stability of bullying victimization: A person-oriented analysis of cyber and traditional bullying experiences among adolescents”. Scandinavian Journal of Psychology, 53, pp. 181-190.

Feinberg, T., Robey, N. (2009). "Cyberbullying: Intervention and prevention strategies". National Association of School Psychologists, 38, pp. 1-5.

Griezel, L., Finger, R. L., Bodkin-Andrews, H. G., Craven, G. R., Seeshing Yeung, A. (2012). "Uncovering the Structure of and Gender and Developmental Differences in Cyber Bullying". The Journal of Educational Research, 105, pp. 442-455.

Hase, N. C., Goldberg, B. S., Smith, D., Stuck, A., Campain, J. (2015). “Impacts of traditional bullying and cyberbullying on the mental health of middle school and high school students". Psychology in the Schools, 52(6), pp. 607-617.

Hinduja, S., Patchin, W. J. (2010). “Bullying, Cyberbullying, and Suicide”. Archives of Suicide Research, 14, pp. 206-221.

Jose, E. P., Kljakovic, M., Scheib, E., Notte, O. (2011). “The Joint Development of Traditional Bullying and Victimization With Cyber Bullying and Victimization in Adolescence". Journal of research on adolescence, 22(2), pp. 301-309.

Machackova, H., Pfetsch, J. (2016). "Bystanders' responses to offline bullying and cyberbullying: The role of empathy and normative beliefs about aggression". Scandinavian Journal of Psychology, 57, pp. 169-176.

Menesini, E., Nocentini, A., Camodeca, M. (2013). “Morality, values, traditional bullying, and cyberbullying in adolescence". British Journal of Developmental Psychology, 31, pp. 1-14.

Morrow, A., Downey, C. A. (2013). "Perceptions of adolescent bullying: Attributions of blame and responsibility in cases of cyber-bullying". Scandinavian Journal of Psychology, 54, pp. 536-540.

Olweus, D. (2012). “Cyberbullying: An overrated phenomenon?”. European Journal of Developmental Psychology, 9, pp. 520-538.

O’Moore, M. (2012). “Cyber-bullying: the situation in Ireland”. Pastoral Care in Education, 30(3), pp. 209-223.

Opsenica Kostić, J., Panić, T., Cakić, V. (2015). “Karakteristike nosilaca uloga u elektronskom maltretiranju" [Characteristics of the main actors in electronic bullying]. Primenjena psihologija, 8(2), pp. 131-146. 
Özdemir, Y. (2014). "Cyber victimization and adolescent self-esteem: The role of communication with parents". Asian Journal of Social Psychology, 17, pp. 255-263.

Ryan, K. N., Curwen, T. (2013). "Cyber-Victimized Students: Incidence, Impact, and Intervention”. SAGE Open, 3(4), pp. 1-7.

Salmivalli, C. (1999). "Participant role approach to school bullying: implications for interventions”. Journal of adolescence, 22(4), pp. 453-459.

Salmivalli, C. (2001). Group view on victimization: Empirical findings and their implications. Ed. J. Juvonen \& S. Graham. Peer harassment in school - The plight of the vulnerable and victimized. (pp. 398-419). New York: The Guilford Press.

Salmivalli, C. (2010). "Bullying and the peer group: A review". Aggression and violent behavior, 15(2), pp. 112-120.

Salmivalli, C., Huttunen, A., Lagerspetz, M. J. K. (1997). "Peer networks and bullying in schools". Scandinavian journal of psychology, 38(4), pp. 305-312.

Salmivalli, C., Isaacs, J. (2005). "Prospective relations among victimization, rejection, friendlessness, and children's self- and peer-perceptions". Child development, 76(6), pp. 1161-1171.

Salmivalli, C., Kaukiainen, A., Kaistaniemi, L., Lagerspetz, M. J. K. (1999). „Self-evaluated self-esteem, peer-evaluated self-esteem, and defensive egotism as predictors of adolescents' participation in bullying situations". Personality and social psychology bulletin, 25(10), pp. 1268-1278.

Salmivalli, C., Kaukiainen, A., Voeten, M. (2005). Anti-bullying intervention: Implementation and outcome. British journal of educational psychology, 75(3), pp. 465-487.

Salmivalli, C., Voeten, M., Poskiparta, E. (2011). “Bystanders matter: Associations between reinforcing, defending, and the frequency of bullying behavior in classrooms". Journal of clinical child and adolescent psychology, 40(5), pp. 668-676.

Twemlow, W. S., Sacco, C. F. (2008). Why school antibullying programs don't work. USA: Jason Rowman and Littlefield Publishers.

Yang, S-J., Stewart, R., Kim, J-M., Kim, S-W., Shin, I-S., Dewey, E. M., Maskey, S., Yoon, J-S. (2013). "Differences in predictors of traditional and cyber-bullying: a 2-year longitudinal study in Korean school children". European Child and Adolescescent Psychiatry, 22(5), pp. 309-318.

\section{ELEKTRONSKO NASILJE MEĐU ŠKOLSKOM DECOM}

Apstrakt: Savremene informaciono-komunikacione tehnologije nailaze na široku upotrebu u svakodnevnoj komunikaciji među odraslima i mladima. Pored benefita koje sa sobom nosi korišćenje savremenih medija, otvara se mogućnost njihove zloupotrebe u cilju povređivanja drugih osoba. Među učenicima je kao forma neadekvatnog korišćenja savremenih medija zastupljeno elektronsko nasilje. Kako je dati fenomen novijeg datuma, a načini njegovog ispoljavanja sa razvojem savremenih medija sve složeniji, javlja se potreba boljeg razumevanja specifičnosti $i$ načina ispoljavanja ove vrste vršnjačkog 
nasilja. Rad ima za cilj da ukaže na značenje termina elektronsko nasilje, na oblike njegovog ispoljavanja, učesničke uloge u elektronskom nasilju, ali i na posledice takvog ponašanja, kako bi se dati fenomen bolje razumeo i kako bi školsko osoblje moglo da radi na njegovom suzbijanju.

Ključne reči: elektronsko nasilje, oblici elektronskog nasilja, klasično nasilje, nasilnici, žrtve, posmatrači 